\title{
Measuring Technical Drawing Capability through Online Learning as a Basic Competency for Vocational Students
}

\author{
Aan Sukandar ${ }^{1,2} *$, Bahtiar Hasan ${ }^{3}$, Tuti Suartini ${ }^{3}$ \\ ${ }^{1}$ Program Pendidikan Teknologi Kejuruan, Sekolah Pasca Sarjana, Universitas Pendidikan Indonesia \\ ${ }^{2}$ Departemen Pendidikan Teknik Mesin, Universitas Pendidikan Indonesia, Jl. Dr. Setiabudi No. 229 Bandung, Indonesia \\ ${ }^{3}$ Departemen Pendidikan Teknik Elektro, Universitas Pendidikan Indonesia, Jl. Dr. Setiabudi No. 229 Bandung, Indonesia \\ ${ }^{1}$ aan.sukandar@upi.edu, ${ }^{3}$ bachtiarhasan55@yahoo.com, ${ }^{3}$ tutisuartini@upi.edu
}

\begin{abstract}
The ability to read projection systems and describe projections of real objects in two-dimensional space are two important things that can lead potential engineering personnel to become professional vocational personnel in mechanical engineering. Therefore, this research is conducted to measure these abilities based on online learning activities in mechanical engineering drawing. There are two research variables used, namely reading and drawing on projection material. The quantitative descriptive method is used to process data on learning outcomes from these two variables collected from the online survey through structured assignments given to students. It can be concluded that the students could understand basic competency learning activities of projection images and complete drawing work which is distributed online properly. They could also complete the assignments according to the specified time given. Thus, drawing technique practices in the era of reality and virtual integration does not always require direct guidance from the supervisor. The online vocational education model can be developed for technology fields that require engineering technology skills in collaboration with the industry.
\end{abstract}

Keywords: drawing machine, drawing mechanical engineering, online learning, orthogonal projection, pictorial projection.

\footnotetext{
Corresponding Author

*Departemen Pendidikan Teknik Elektro, Universitas

Pendidikan Indonesia, J1. Dr. Setiabudi No. 229

Bandung, Indonesia

* tutisuartini@upi.edu

**Departemen Pendidikan Teknik Mesin, Universitas

Pendidikan Indonesia, Jl. Dr. Setiabudi No. 229

Bandung, Indonesia
}

\section{**aan.sukandar@upi.edu}

\section{Introduction}

Engineering drawing is a working mechanism in a company. Problems that often occur in this mechanism are misreading of the image and making the image size wrong. These mistakes are very fatal because the drawings cannot be used to communicate properly in the design process and the results of the products are not according to the plan. The workpiece sketch is subjected to provide information that will help workers to understand the image and act accordingly. Engineering drawings of workpieces may be quite difficult for vocational high school students. The appearance of projected images is an important topic in the engineering drawing course that teaches students to be able to draw regularly and according to the rules of the ISO Standard (Sato, 2013).

The purpose of this study is to measure the reading and drawing skills used in online learning. In traditional mechanical engineering drawing learning activities, it is usually conducted using a drawing table in a special drawing room. In online learning, mechanical engineering drawings for drawing activities are carried out individually. This research is conducted to support the existence of an Integrated Learning System called SPOT as one of the online learning infrastructures at the Universitas Pendidikan Indonesia and to examine the development of learning material content through ICT literacy. This research will also examine whether the delivery infrastructure, quality control, and student support are existing in the online courses, as these aspects greatly determine the quality of online learning (Van Bruggen, 2005).

Research on measuring the ability to draw mechanical engineering is different from the ability to draw simple symbols or diagrams in other areas of vocational expertise. A mechanical engineering drawing is an image to express detailed and clear drawing ideas to be actualized into a real object, or a working manual containing work drawing 
information in a small size of a workpiece (metal) and the technical drawing of the workpiece is to guide workers in the vocational engineering field to do work following the workpiece or the ability to act in a relevant manner (Nolker and Schoenfeid, 1983). Measurement of technical drawing capability is indispensable to determine the ability of workers to act relevantly to the workpiece. A good workpiece drawing work is an image that displays a clear and easy-to-read size, it must be readable nationally and internationally (Sato, 2013). A sketch image that has information to produce, measure, and test, and can be installed into a production object that is expected to develop various development innovations from equipment for the machine industry. Needless to say, it will not be successful if the quality of human resources needed by the workplace and industry do not master the basic science of drawing mechanical engineering. Higher education is currently expected to produce graduates who can become lifelong learners throughout their working lives. Online learning is a form of obtaining your learning material outside of formal education, in real-life work settings (Cremers, Wals, Wesselink, Nieveen, and Mulder, 2014).

There are some examples of teaching technical drawing to engineering students from engineering history since the era of Leonardo da Vinci to the era of digital technology contributing to the two-dimensional graphic representation of three-dimensional machines supported in perspective, drawings, and descriptive notes are the parameters used to develop digital drawing technology. Even Gaspar Monge's influence in the graphic documentation of a project is enormous, with his new science, Descriptive Geometry; the director of Portugal's first technical school, Alfredo Bensaude, acknowledges the practice of executing drawings is important for training engineers (Sampaio, 2018). In measuring the ability of the technical drawing, the most important topic is to assess the qualifications of the capacity to draw according to the regulations, since the technical drawing is a collection of standard rules and technical documentation that facilitates communication between the project collaborators.

\section{Theoretical Framework}

Mechanical engineering design is a globally applicable machine design communication language. Projection is a way to create objects in the form of images. Mechanical engineering drawings are images of machine parts that are displayed in cross-sectional form from the top view, side view, and front view to express the shape of the object through projection. In mechanical engineering, drawings can be geometric shapes on the floor plan, cut pieces, depiction of machine parts (threads, weld joints), three-dimensional cross-sections, and visible drawings (top, side) (Nolker and Schoenfeid, 1983). Educational institutions that produce vocational educators must have the capacity to produce professional workers oriented to the workplace. Some research stated that the vocational school students who are given worksheets have better ability in basic competence of reading projections than students who read directly from real objects. Following up on the results of this study, mechanical engineering drawings are the basic competencies that workers and designers must have, especially those who work in the field of machinery and those who develop technological and technical innovations. The projected object image is a communication language which is an international agreement for the design of machine parts or workpieces.

The competency standards of graduates used to achieve the abilities used are core competencies consisting of several competencies (Ana, 2020) includes spiritual core competencies, social core competencies, knowledge core competencies, and core skills competencies. Among these competencies, the ones used for professional skill qualifications as vocational educators are knowledge core competencies, and core skills competencies. Indonesian 2013 curriculum is competency-oriented, one of the models that have begun to use is blended learning (Graham, 2006). Blended learning design of Computer-Aided Design (CAD) course is one of the engineering drawing courses that is actualized in practice in the computer room and online learning navigated by course sites. Blended learning is a teaching strategy that has been widely used because traditional learning cannot meet the demands of teaching to read and create CAD-based drawing. Therefore, studying how to measure and measuring the results of online learning is very important (Li, Zhou, Fang, and Dai, 2011).

Measuring the basic competence of engineering students in the field of projection expertise is an indispensable problem in the modern education system and the curriculum that follows because most of the application of technology is the visualization of images that are converted into electrical signals. From visual drawing technology to forming various drawing designs, it requires expertise in drawing projection rules to be communicated. In the subject of computer-based technical drawing, adequate theoretical training and practical training are required, including how to draw and make use of pens and tools on paper. Drawing using a computer as suitable software is a pen-to-paper drawing sketch, and the final CAD software has become a widely accepted piece of engineering work. Spatial visualization skills are skills in which the application of new technologies and special software has a positive and negative impact. Thus, the importance of drawing techniques as a basic skill for all engineering fields needs to be improved and become a challenge for researchers who researched the skills and achievements of spatial visualization in Drawing Engineering subjects to be developed on mobile devices for students at the University of Belgrade (Trifunović, Čičević, Lazarević, Dragović, and Čučaković, 2019).

According to the previous research, the Machine Drawing material is divided into three parts. Part I discusses the basic principles of technical drawing, dimensions, boundaries, suitability, and tolerances. Part II provides details on how to draw and assemble machine components for assembly drawings. Part III contains problems with assembly drawings taken from various fields of mechanical, production, automobile, and marine engineering. An engineer is required to translate his engineering ideas or 
ideas into an image. The engineer ability to make drawings is determined by how much he knows about the rules of technical drawing standards. A person's knowledge of image standards determines how much a person can read an image (Mustalikin, 2018). This means that the ability to create and read images is very important for a technician's career. The design of an object that will be transformed into a real object must be designed in a way called projection. A projected image is a picture of a real or imaginary object depicted according to the observer's line of sight on a flat plane (image plane) (Sulardjohadi, 1984). Fundamentals on design and visualization for computer modelling, as well as more traditional technical drawing methods in engineering drawings for welding and manufacturing engineering instructions (Oppermann, 1941).

The scope of the basic competencies of technical drawing in the Indonesian 2013 curriculum is basic competencies that must be possessed to be able to read and draw using CAD technology. To illustrate the importance of online learning that the core competencies of basic technical drawing skills in the core competencies and the skills to make drawings better using online learning. It is assumed that it will further increase creativity, literacy, responsibility and discipline, as depicted in Table 1 Noriega (2016).

Table 1 shows the minimum abilities required as basic competence for vocational students is the ability to analyze pictorial and orthogonal projections, which means being able to read and describe workpieces for KI 3 and KI 4 in the field of projection expertise displaying a pictorial (3D) projection image displaying quadrant, I and quadrant III (2D) orthogonal projection images. There are two groups of projections in the ISO system, namely pictorial projections, and orthogonal projections (Juhana and Suratman, 2000). Pictorial projection is a way of displaying an image of an object that is closer to its true shape and size in three dimensions, with a single view (Juhana and Suratman, 2000). Figure 1 shows one way of drawing.

Orthogonal projection is to display objects in two dimensions. Completeness of information and accuracy regarding the shape and size of an object is a picture of the view from several directions front, back, up, down, left, and right. There are two systems used, namely the European system and the American system. An example of an object projected orthogonally using the European projection is shown in Figure $2 \mathrm{a}$ and the orthogonal projection of the American system in Figure $2 b$.

Figures 1, 2a, and $2 \mathrm{~b}$ are the scope of the basic competencies of the projected image. The ability to understand technical drawings, especially in projections is the skills to read images and make pictures as a vocational teacher as stated in the 2013 curriculum. The implementation of the curriculum shows that the quality assurance of learning quality in the schools can produce graduates who have skill competencies. Competency standards for graduates are part of the Indonesian Education Standards for quality assurance of the ISO 9001: 2008 standard that has been implemented in the educational institutions. The 2013 curriculum is the digital era curriculum use in vocational schools to deal with various technological changes.

Table 1. Basic Competency of Drawing Technique Skills for Vocational high schools

\begin{tabular}{|r|l|l|}
\hline \multirow{2}{*}{ No. } & \multicolumn{2}{|c|}{ BASIC COMPETENCIES } \\
\cline { 2 - 3 } & \multicolumn{1}{|c|}{ Knowledge (KI3) } & \multicolumn{1}{c|}{ Skills (KI4) } \\
\hline 1. & $\begin{array}{l}\text { Understand the function of equipment } \\
\text { and the completeness of technical } \\
\text { drawings }\end{array}$ & $\begin{array}{l}\text { Sorting equipment and } \\
\text { completeness of } \\
\text { technical drawings }\end{array}$ \\
\hline 2. & $\begin{array}{l}\text { Understand the types and functions of } \\
\text { engineering drawing lines }\end{array}$ & $\begin{array}{l}\text { Place the outline of } \\
\text { the engineering } \\
\text { drawing }\end{array}$ \\
\hline 3. & $\begin{array}{l}\text { Understand the standard letters, and } \\
\text { numbers of engineering drawings }\end{array}$ & $\begin{array}{l}\text { Placing letters, and } \\
\text { figures of engineering } \\
\text { drawings }\end{array}$ \\
\hline 4. & $\begin{array}{l}\text { Apply a geometric construction } \\
\text { drawing }\end{array}$ & $\begin{array}{l}\text { Shows a geometric } \\
\text { construction drawing }\end{array}$ \\
\hline 5. & $\begin{array}{l}\text { Understand the rules of engineering } \\
\text { drawing etiquette }\end{array}$ & $\begin{array}{l}\text { Put engineering } \\
\text { drawing labels }\end{array}$ \\
\hline 6. & $\begin{array}{l}\text { Analyzing the pictorial projection } \\
\text { image design (3D) }\end{array}$ & $\begin{array}{l}\text { Displaying a pictorial } \\
\text { (3D) projection image }\end{array}$ \\
\hline 7. & $\begin{array}{l}\text { Analyze the design of quadrant I and } \\
\text { quadrant III (2D) orthogonal } \\
\text { projection images }\end{array}$ & $\begin{array}{l}\text { Displaying quadrant, I } \\
\text { and quadrant III (2D) } \\
\text { orthogonal projection } \\
\text { images }\end{array}$ \\
\hline 8. & $\begin{array}{l}\text { Evaluating cutout images } \\
\text { image }\end{array}$ & $\begin{array}{l}\text { Designing a cutout } \\
\text { image }\end{array}$ \\
\hline 9. & $\begin{array}{l}\text { Designing the size of } \\
\text { the image. }\end{array}$ \\
\hline
\end{tabular}

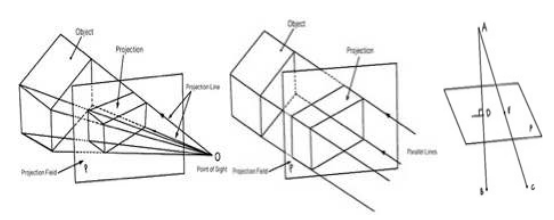

Fig 1. Pictorial Projection (Sato. 2013)

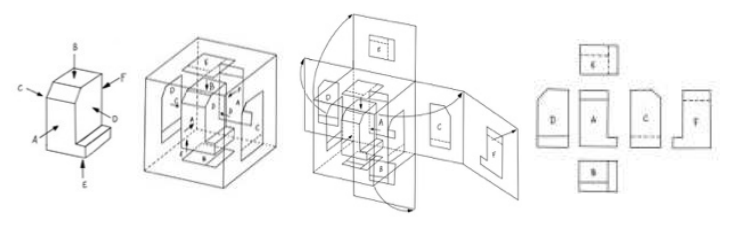

Fig 2. European projections (Sato, 2013)

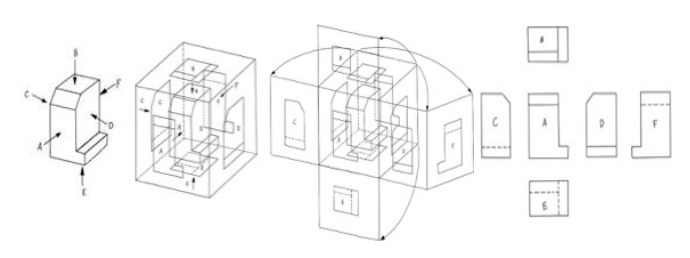

Fig. 3. American projection (Sato, 2013) 
Changes in the reality of mass education-based education implemented face-to-face, the results of which can directly produce good learning outcomes with the 2013 curriculum do not guarantee the quality of learning outcomes towards the ability to increase individual creativity. Korea as one of the countries that have succeeded in developing ICT technology shows that face-to-face education policies are not suitable for fostering creative and talented students. Therefore, the Korean government is working to change all aspects of the education system and curriculum and target a personal learning system that takes into account the characteristics of each student. Nowadays, Korean education emphasizes creativity, fusion, and collaboration and looks for better methods and programs such as reverse learning, MOOCs, and online courses for the era of the Fourth Industrial Revolution (Park, 2020).

The competence of vocational education students in understanding the subject of mechanical engineering drawing, especially on learning outcomes of competency in reading images of orthogonal projection techniques is still lacking as they still often misread images and show errors in making image sizes. These mistakes will be very fatal because technical drawing as a technical language is a work communication tool and if the product made is not following product planning, it can fail. Besides, the ability to misread workpiece projection rules that still often occur in vocational high school graduates is something that will always happen (Sutirja, 2019). In the ability to draw orthogonal projection SketchUp media is used and it has better learning outcomes using the method of drawing tools. This shows the assumption that the application of a technology-based learning model is necessary to be implemented seriously (Waluya and Wiyono, 2015).

To make activities virtual learning models or online learning successful, a teacher must have the ability as a virtual leader (Reinig, 2010). The way virtual team leaders succeed requires the ability to build and maintain trust through the use of communication technology, ensure that the distributed diversity is understood and valued, manage the virtual work life cycle, monitor student progress in using technology, increase the visibility of virtual students inside and outside the classroom, and allow individual students from learning activities to benefit from virtual classes.

\section{Method}

This research is descriptive and the respondents are students of Mechanical Engineering Education who are observed in learning activities. The activity process uses a predetermined online learning activity protocol (Al-Qahtani et al., 2013). The empirical study of online learning used is by observing face-to-face learning conditions and measure student learning outcomes using a research design that is following the conditions of students and lecturers. Real research information following the conditions will provide information to assess whether average students under online learning conditions are learning. The theoretical model views that the creation of an effective online educational community involves three important components which are cognitive presence, social presence, and teaching presence.

This model is developed and validated through content analysis and other qualitative and quantitative measures. The data collection techniques and instruments are taken by using interviews, question and answer, and assignments to students accompanied by documentation data sent through the ICT integrated learning system (SPOT) managed by Universitas Pendidikan Indonesia, Bandung. 34 students are attending the lecture. The technical drawing online learning is the course contract that the student must take.

The definition of basic competency is the ability and learning material for a subject in each educational unit which refers to the core competencies that have been defined and have been used and developed in the curriculum for educational development. Measurement of ability in Technical Drawing is the expertise competency in the mastery of techniques or reading images and describing in understanding the basics and principles of drawing according to International Organization for Standardization (ISO).

\section{Results and Discussion}

Students ability to read an object with an image that has been projected from the material source of technical drawing rules is observed. The results of learning in student learning activities show that it is interactive in improving technical drawing skills in online learning activities (Setianingrum, 2017). Most students stated that they could understand the material which means that most of the students comprehend and can make projection images following G. Takeshi Sato in the book Drawing Machines According to ISO Standards. It is revealed that to be able to draw projections well, students must first understand about correct axonometric projection image, correct orthogonal projection image, correct understanding of European projection system, correct understanding of American projection system, design of images with correct European projection systems, and understanding the image design with American system projection correctly (Sato, 2013).

In Table 2, it can be seen that the trend of the product variables with the most effective mean and standard deviation can be carried out according to the learning activity plan. Furthermore, the results of the indicator analysis obtained from the trend category analysis of each indicator draw projections and views, based on the calculation results obtained by the mean standard value for each competency as in Table 2.

In Table 2, the reading variable is an indicator taken from Table 1 (based on basic competencies 3.6 and 3.7) which are the skills of core competencies in communication purposes (Juhana and Suratman, 2000). A graphic image is a geometric representation of a graph that depicts the information and image applications required for machine technology. Graphic images are pictures that are used in all science and technology to represent material, so they are easier to interpret and easier to understand (Bhatia, Lad, and 
Kumar, 2018). The system used for drawing graphical algorithms is the first to be used for visualization purposes for the development of various computer technologies used for visualization. Graphical images are also used in planning for VLSI, VLSI layout, circuit schematics, data flow images, and RNA genomics. Of the various implementations, emphasizing the ability to read projections and describe the visualization of objects is an aspect of mastering basic competency skills that is most likely for students to develop themselves optimally. By using the three assessment indicators for online activity activities using three categories, namely excellent, good, and sufficient. This indicator is to determine the results of the reading ability level and the image realization of the workpiece obtained from the data displayed in online activities as shown in Table 3.

Table 2. The average value of reading and drawing variable mastery in Projection Image Competence to Respondents $(n=34)$

\begin{tabular}{|l|l|l|l|l|l|l|l|}
\hline Variable & Indicator & \multicolumn{6}{|c|}{ Mean (Scale 0-4) } \\
\cline { 3 - 8 } & & \multicolumn{2}{|c|}{ Pictorial Projection } & \multicolumn{3}{|c|}{$\begin{array}{l}\text { Orthogonal } \\
\text { Projection }\end{array}$} \\
\cline { 3 - 8 } & & Max & Mean & SD & Max & Mean & SD \\
\hline $\begin{array}{l}\text { Reading } \\
\text { machine }\end{array}$ & $\begin{array}{l}\text { Projection } \\
\text { line }\end{array}$ & 4.00 & 3.75 & 0.41 & 4.00 & 3.50 & 0.49 \\
\cline { 2 - 8 } & $\begin{array}{l}\text { Projection } \\
\text { plane of } \\
\end{array}$ & 4.00 & 3.67 & 0.39 & 4.00 & 3.45 & 0.46 \\
\cline { 2 - 8 } & $\begin{array}{l}\text { Thects } \\
\text { form of } \\
\text { the } \\
\text { projection }\end{array}$ & 4.00 & 3.50 & 3.50 & 4.00 & 3.61 & 0.49 \\
\hline \multirow{2}{*}{$\begin{array}{l}\text { Drawing } \\
\text { machine }\end{array}$} & Face & 4.00 & 3.75 & 0.41 & 4.00 & 3.67 & 0.39 \\
\cline { 2 - 8 } & Top view & 4.00 & 3.71 & 0.36 & 4.00 & 3.50 & 0.49 \\
\cline { 2 - 8 } & Side view & 4.00 & 3.50 & 0.49 & 4.00 & 3.50 & 0.49 \\
\hline
\end{tabular}

Table 3 Average reading score in online activities and indicates assignments that have been submitted and submitted online $(n=34)$

\begin{tabular}{|c|l|c|c|c|c|c|c|}
\hline Variable & Indicator & \multicolumn{6}{|c|}{ Mean (\%) } \\
\cline { 3 - 8 } & & \multicolumn{2}{|c|}{ Pictorial Projection } & \multicolumn{2}{|c|}{ Orthogonal Projection } \\
\cline { 3 - 8 } & $\begin{array}{l}\text { Very } \\
\text { Good }\end{array}$ & Good & Fair & $\begin{array}{l}\text { Very } \\
\text { Good }\end{array}$ & Good & Fair \\
\hline $\begin{array}{c}\text { Reading machine } \\
\text { (R) }\end{array}$ & $\begin{array}{l}\text { Projection } \\
\text { line }\end{array}$ & 90.01 & 9.00 & 1.00 & 92.00 & 7.00 & 1.00 \\
\hline & $\begin{array}{l}\text { Projection } \\
\text { plane of } \\
\text { objects }\end{array}$ & 86.02 & 10.00 & 4.00 & 86.00 & 10.00 & 4.00 \\
\hline & $\begin{array}{l}\text { The real } \\
\text { form of } \\
\text { the } \\
\text { projection }\end{array}$ & 90.01 & 8.00 & 2.00 & 86.00 & 10.00 & 4.00 \\
\hline & $\sum \mathrm{R}$ & 88.67 & 9.00 & 2.33 & 88,00 & 9.00 & 3.00 \\
\hline Drawing machine & Face & 86.01 & 10.00 & 4.00 & 90.00 & 6.00 & 4.00 \\
\hline (D) & Top view & 86.10 & 10.00 & 4.00 & 86.00 & 10.00 & 4.00 \\
\hline & Side view & 86.02 & 10.00 & 4.00 & 86.00 & 10.00 & 4.00 \\
\hline & $\sum$ D & 86.00 & 10.00 & 4.00 & 87.30 & 8.67 & 4.00 \\
\hline Basic competencie & $\begin{array}{l}\text { Mean }= \\
\sum R+\sum \boldsymbol{D}\end{array}$ & 87.34 & 9.50 & 3.17 & 87.65 & 8.84 & 3.50 \\
& $\frac{2}{2}$ & & & & & & \\
\hline
\end{tabular}

Based on the results of the respondents' activities, students who attend the technical drawing learning in Table
3 shows that of the three indicators reading the pictorial projection image $88.67 \%$, and $88.00 \%$ orthogonal projection, students can describe it. Meanwhile, the ability to describe the pictorial image is remarkable $86.00 \%$ and orthogonal drawings $(87.65 \%)$. Online activities allow data on work results shown in time so students show a responsibility to complete assignments and take online learning seriously (Van Bruggen, 2005). The data in Table 3 shows that most of the students can acquire the basic competency of mechanical engineering drawings distinctively, with the ability to acquire basic competency is mastery of techniques or reading pictures in understanding the basics and principles of drawing according to International Organization for Standardization (ISO) standards. Thus, basic competency is the average competency of students' skills in reading and drawing, which can be used in the development of reading and drawing in the machine industry.

It is sufficient to provide the ability for vocational education competency standards of expertise for each individual who can read and draw, so it can be said to have basic competencies. Thus, the initial theory of online learning as online participation in learning technical drawings is a complex process in taking part and maintaining relationships with others, supported by physical and psychological tools, not synonymous with speaking or writing, as it is supported by all kinds of interesting activities (Hrastinski, 2009).

Table 2 shows the results of the research and the average ability level is remarkable, it can be assumed that students can learn 'hands-on' activities through online learning. Multimedia system applications used for online learning can be used to demonstrate reading and drawing skills both online and offline. Therefore, students can draw through technology. One of the technologies that have been developed for mechanical engineering drawings is known as AUTOCAD. AUTOCAD as a multimedia tool can be used for various needs of projection images (Mahazir I., Norazah, Ridzwan, and Azwin Arif, 2013). From the evaluation conducted, the researchers show a better ability compared to hands-on technology.

Besides, online learning can be defined as a learning process through mobile devices, such as tablets and handheld computers, MP3 players, smartphones, and cellphones as an innovation for the needs of digital technology education among students, which has been implemented in various online learning activities (Salleh, Minhat, and Baharuddin, 2017). Based on the data obtained, online learning results for technical drawing activities can be said to be successful. This also indicates that online learning activities have become part of learning activities for the future following technological developments (Van Bruggen, 2005). Therefore, vocational students who learn online need to be developed because based on the research that has been done using the Discovery Teaching model shows higher learning outcomes than traditional learning (Chang, 2012). 


\section{Conclusion}

The ability to read and draw techniques through online learning can be done and shows good results. All students can complete their tasks without any significant disturbances and obstacles. Both students and teachers can carry out Mechanical Engineering Drawing learning activities for basic orthogonal competencies and image projection. Thus, online learning activities can be a model for overcoming space limitations and a tool for carrying out mechanical engineering drawing practicum activities. In addition, the implications of learning to draw mechanical engineering online can be part of learning activities that will make it easier to practice reading and drawing machine products following the machines used in the industrial and business world.

\section{References}

Al-Qahtani, H., Aqeel, S., Barnieh, H., Gouba, A., Hjeij, D., Salem, M., and Kerr, T. (2013). An Investigation into the Preparation of High School Students to Pursue an Engineering Career. Procedia - Social and Behavioral Sciences. 102, 340-351.

Ana, A. Trends in Expert System Development: A Practicum Content Analysis in Vocational Education for Over Grow Pandemic Learning Problems. Indonesian Journal of Science and Technology, 5(2), 71-85.

Bhatia, S., Lad, K., and Kumar, R. (2018). Bend-optimal orthogonal drawings of triconnected plane graphs. AKCE International Journal of Graphs and Combinatorics. 15 (2). 168-173.

Chang, C.H. (2012). Apply discovery teaching model to instruct engineering drawing course: Sketch a regular pentagon. Procedia - Social and Behavioral Sciences. 64, 457-488.

Cremers, P. H. M., Wals, A. E. J., Wesselink, R., Nieveen, N., and Mulder, M. (2014). Self-directed lifelong learning in hybrid learning configurations. International Journal of Lifelong Education, 33(2), 207-232.

Graham, C. R. (2006). Introduction to Blended Learning. Handbook of Blended Learning Global Perspectives Local Designs.

Hrastinski, S. (2009). A theory of online learning as online participation. Computers and Education. 52(1), 78-82.

Juhana, O., Suratman, M. (2000). Menggambar Teknik Mesin dengan standar ISO CV Pustaka Setia.

Li, H., Zhou, D., Fang, L., and Dai, M. (2011). The application of blended learning in the teaching design of Computer Aided Design. In 2011 International Conference on Control, Automation and Systems Engineering, (CASE) (pp.1-3.IEEE.

Mahazir I., I., Norazah, M. N., Ridzwan, C. R., and Azwin Arif, A. A. (2013). Relationship between the acceptance of mobile learning for AutoCAD course and learning style in polytechnic. Procedia - Social and Behavioral Sciences. 102, 177-187.

Mustalikin, M. (2018). Flexible Box Untuk Meningkatkan Keterampilan Menggambar Teknik Sistem Proyeksi
Amerika Dengan Menggunakan Pendekatan Scientific Pada Peserta Didik Kelas X.Bo.1 Di Smk Negeri Kebasen Semester 2 Tahun Pelajaran 2016/2017. Widya Komunika. 8 (1), 46-65.

Nolker, H., and Schoenfeid, E. (1983). Berufsbildung untericht, Curriculum, Planungtle.

Noriega, F. M. (2016). Handbook of Research on Engaging Digital Natives in Higher Education Settings. Handbook of Research on Engaging Digital Natives in Higher Education Settings.

Oppermann, R. H. (1941). Technical drawing. Journal of the Franklin Institute, 231(1), 92-93.

Park, Y. C. (2020). History of Korean education and the fourth industrial revolution. History of Education and Children's Literature, 15(1), 431-444.

Reinig, M. (2010). The theory and practice of online learning. Language, Learning and Technology. 14(1), 24-27. Salleh, Y., Minhat, N., and Baharuddin, R. (2017). Perception on the readiness of application mobile learning in digital technology education. Advanced Journal of Technical and Vocational Education 1(2), 41-45.

Sampaio, A. Z. (2018). Historical evolution of technical drawing in engineering. In 3rd International Conference of the Portuguese Society for Engineering Education, CISPEE (pp. 1-9).IEEE.

Sato, G. T. (2013). Menggambar Mesin: Menurut Standar ISO. PT. Pradnya Paramita.

Sulardjohadi. (1984). Gambar proyeksi metode dan Macamnya.

Setianingrum, M. (2017). Penggunaan Variasi Media Ajar Terhadap 3 Gaya Belajar Siswa Dalam Pembelajaran Bahasa Jepang. JAPANEDU: Jurnal Pendidikan dan Pengajaran Bahasa Jepang, 2(1), 1-8.

Sutirja, S. (2019). Peningkatan hasil belajar peserta didik tentang membaca gambar teknik proyeksi ortogonal melalui penerapan model pembelajaran koperatif tipe student teams achievement division (STAD) di SMK Negeri 2 kota Bogor. Jurnal Teknologi Pendidikan, 8(1), 85-105.

Trifunović, A., Čičević, S., Lazarević, D., Dragović, M., and Čučaković, A. (2019). Challenges and promises of mobile devices usage for spatial visualization skills assessment in technical drawing for engineering course. Advances in Intelligent Systems and Computing, 809, 1740-1750.

Van Bruggen, J. (2005). Theory and practice of online learning. British Journal of Educational Technology, 36(1), 111-112.

Waluya, S., and Wiyono, A. (2015). Pengaruh media pembelajaran menggunakan program sketchup terhadap kemampuan menggambar proyeksi ortogonal siswa di SMK Negeri 2 Surabaya. Jurnal Kajian Pendidikan Teknik Bangunan, 3(3), 57-74. 